\title{
PEMANFAATAN RAPID MINER STUDIO 8.2 UNTUK PENGELOMPOKAN DATA PENJUALAN AKSESORIS MENGGUNAKAN ALGORITMA K-MEANS
}

\author{
Mardalius \\ Program Studi Sistem Informasi, STMIK Royal Kisaran \\ Jl. Prof. M. Yamin 173 Kisran, Sumatera Utara 21222 \\ Email : mardalius@royal.ac.id
}

\begin{abstract}
At Rafadel Store Acc various types of accessories available that are sold in the Store. Of the various types of accessories are sold certainly not all of them sold and also there are less salable and some are never sold at all. With this problem then we need to do calculations to determine or classify which categories of accessories that sell, sell and sell unsold, in the process of grouping it will be used a method of clustering using K-Means Clustering Algorithm as a method of calculation manually and in the implementation then used a Data Mining software using RapidMiner Studio version 8.2. With the RapidMiner Studio application store owners can see the results of the grouping which accessories are the most salable, sellable and less salable. So, if there are products that do not sell, shop owners can look for other alternatives to unsold accessories that can be sold. The method used in data collection is observation and interview to Rafadel Acc shop owner.
\end{abstract}

Keywords: Data Mining, K-Means, Clustering, Store, Accessories

\begin{abstract}
Abstrak: Pada toko Rafadel Acc menjual berbagai jenis aksesoris yang tersedia yang dijual di toko tersebut. Dari berbagai jenis aksesoris yang dijual tentu tidak semuanya yang laku terjual dan juga ada yang kurang laku serta ada juga yang tidak pernah terjual sama sekali. Dengan adanya masalah ini maka kita perlu melakukan perhitungan untuk menentukan atau mengelompokkan mana kategori aksesoris yang laku, kurang laku dan tidak laku terjual, dalam proses pengelompokan maka akan digunakan sebuah metode pengelompokan menggunakan Algoritma K-Means Clustering sebagai metode perhitungan secara manual dan dalam implementasinya maka digunakan sebuah software Data Mining menggunakan RapidMiner Studio versi 8.2. Dengan adanya aplikasi RapidMiner Studio ini pemilik toko dapat melihat hasil pengelompokan aksesoris mana yang paling laku, laku dan kurang laku. Maka, bila terdapat produk yang tidak laku, pemilik toko dapat mencari alternative lain agar aksesoris yang tidak laku dapat menjadi laku. Metode yang digunakan dalam pengumpulan data adalah observasi dan wawancara kepada pemilik toko Rafadel Acc.
\end{abstract}

Kata kunci: Data Mining, K-Means, Clustering, Penjualan, Aksesoris 


\section{PENDAHULUAN}

Rafadel Acc merupakan salah satu bidang usaha yang bergerak di bidang penjualan aksesoris mulai dari aksesoris laki-laki, perempuan serta anakanak juga tersedia pada toko tersebut. Di mana toko ini setiap harinya harus memenuhi kebutuhan konsumen yang lagi trend saat ini. untuk dapat melakukan hal tersebut, maka mebutuhkan sumber informasi yang cukup banyak untuk dapat dianalisis lebih lanjut. Pada Toko Rafadel Acc terdapat beberapa permasalahan yang selalu muncul mengenai penjualan. Berdasarkan hal tersebut maka diharapkan bisa mepermudah pihak Toko Rafadel Acc dalam menemukan informasi dari kumpulan-kumpulan data yang berguna bagi Toko Rafadel Acc. Tidak hanya itu penulis juga mengharapkan bisa memberikan rangsangan kepada pengelolah data supaya lebih aktif dalam menggali informasi yang dibutuhkan oleh Toko Rafadel Acc, sehingga bisa menjawab kebutuhan dari Toko tersebut. Penulis berharap dapat membantu memberikan informasi mengenai hasil Clustering data penjualan. Dengan demikian, dibutuhkan analisis yang komputerisasi menggunakan software data mining yang menunjang arus data dan informasi sesuai dengan kebutuhan dari proses-proses tersebut.

Knowledge discovery in Database (KDD) didefinisikan sebagai ekstraksi informasi potensial, implisit dan tidak dikenal dari sekumpulan data. Proses knowledge discovery melibatkan hasil dari proses data mining (proses mengekstrak kecenderungan pola suatu data), kemudian mengubah hasilnya secara akurat menjadi informasi yang mudah dipahami (Ronald, 2015). Proses knowledge discovery in database (KDD) secara garis besar terdiri dari Data Selection, Pre-processing/Cleaning, Transformation, Data mining, dan Interpretation/Evaluation.
Algoritma K-Means merupakan algoritma non hirarki yang berasal dari metode data clustering, Menurut Eko Prasetyo (2012) mengatakan bahwa metode K-Means ini mempartisi data kedalam kelompok sehingga data berkarakteristik sama dimasukan kedalam sat kelompok yang sama dan data yang berkarakteristik berbeda dikelompokkan kedalam kelompok yang lain. Adapun tujuan dari pengelompokan data ini adalah untuk meminimalkan fungsi objektif yang diset dalam proses pengelompokan, yang pada umumnya berusaha meminimalkan variasi didalam suatu kelompok dan memaksimalkan variasi antar kelompok

Pemilihan metode K-Means dikarenakan metode ini harus menggunakan data fisik tidak abstrak dan bersifat jelas, hal ini sesuai dengan data yang akan digunakan pada permasalahan di dalam pengelompokan penjualan aksesoris. Selain itu, metode ini bersifat fleksibel sebab pengguna dapat menentukan jumlah cluster yang akan dibuat.

\section{METODOLOGI}

Metodologi dipergunakan oleh penulis untuk menganalisa, mengerjakan dan mengatasi masalah yang dihadapi. Kerangka teoritis atau kerangka ilmiah merupakan metode-metode ilmiah yang akan diterapkan dalam pelaksanaan penelitian. Pada kerangka kerja penelitian yang digunakan yaitu mempelajari literatur, mengumpulkan data, menganalisa data, menganalisa metode $\mathrm{K}$ Means, implementasi software, menguji hasil, dan menganalisa hasil.

1. Knowledge Discoveryin Database (KDD)

Knowledge discovery in database (KDD) adalah kegiatan yang meliputi pengumpulan, pemakaian data historis untuk menemukan keteraturan pola atau 
hubungan dalam set data berukuran besar (Buulolo, 2013).

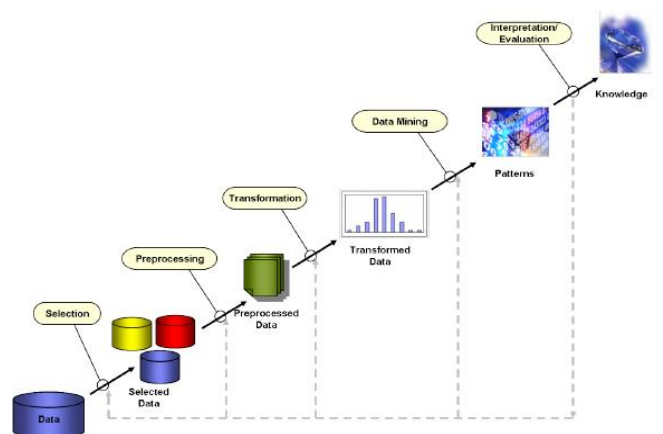

Gambar 1. Aliran Informasi Dalam Data Mining

\section{a. Data Mining}

Menurut Widodo (2013) Data Mining adalah analisa terhadap data untuk menemukan hubungan yang jelas serta menyimpulkannya yang belum diketahui sebelumnya dengan cara terkini dipahami dan berguna bagi pemilik data tersebut.

b. Clustering

Menurut Widodo (2013) Clustering atau klasifikasi adalah metode yang digunakan untuk membagi rangkaian data menjadi beberapa group berdasarkan kesamaan-kesamaan yang telah ditentukan sebelumnya.

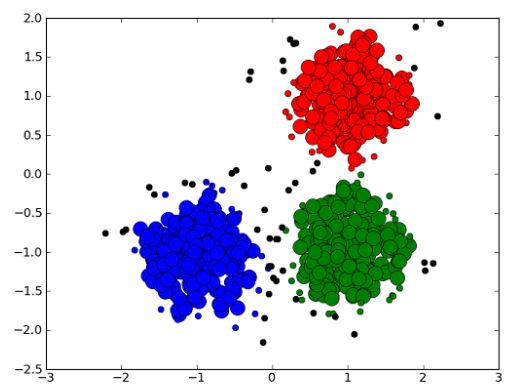

Gambar 2. Clustering

\section{c. Algoritma K-Means}

Menurut Eko Prasetyo (2012) mengatakan bahwa metode $K$-Means ini mempartisi data kedalam kelompok sehingga data berkarakteristik sama dimasukan kedalam sat kelompok yang sama dan data yang berkarakteristik berbeda dikelompokkan kedalam kelompok yang lain.

Langkah-langkah melakukan clustering dengan metode $K$-Means adalah sebagai berikut:

1. Tentukan nilai $k$ sebagai jumlah klaster yang ingin dibentuk.

2. Inisialisasi $k$ pusat cluster ini bisa dilakukan dengan berbagai cara, namun yang paling sering dilakukan adalah dengan cara random yang di ambil dari data yang ada.

3. Menghitung jarak setiap data input terhadap masing - masing centroid menggunakan rumus jarak Euclidean (Euclidean Distance) hingga ditemukan jarak yang paling dekat dari setiap data dengan centroid. Berikut adalah persamaan Euclidian Distance :

$d(x i, \mu j)=\sqrt{\Sigma(x i-\mu j)^{2}}$

Dimana :

$d:$ titik dokumen

$x i$ : data kriteria

$\mu j$ : centroid pada cluster ke- $j$

4. Mengklasifikasikan setiap data berdasarkan kedekatannya dengan centroid (jarak terkecil).

5. Memperbaharui nilai centroid. Nilai centroid baru di peroleh dari rata-rata cluster yang bersangkutan dengan menggunakan rumus:

$$
\mu j(t+1)=\frac{1}{N s j} \sum_{j \in s j} x j
$$

Dimana:

$\mu \mathrm{j}(\mathrm{t}+1)$ : centroid baru pada iterasi ke $(\mathrm{t}+1)$

$\mathrm{Nsj}$ : banyak data pada cluster $\mathrm{sj}$,

6. Melakukan perulangan dari langkah 2 hingga 5,sampai anggota tiap cluster tidak ada yang berubah.

Jika langkah 6 telah terpenuhi, maka nilai pusa cluster $(\mu j)$ pada iterasi terakhir 
Available online at http://jurnal.stmikroyal.ac.id/index.php/jurteksi

akan digunakan sebagai parameter untuk menentukan klasifikasi data.

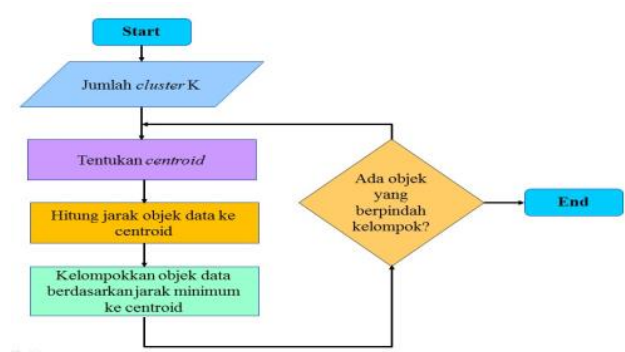

Gambar 3. Flowchart Algoritma K-Means Clustering

\section{HASIL DAN PEMBAHASAN}

Pada proses pengumpulan data ada tiga parameter yang akan digunakan dalam pengolahan data yaitu stok awal, terjual dan stok akhir. Pada penelitian ini data yang dikumpulkan yaitu data penjualan ksesoris pada tahun 2017 Data tersebut diambil dari Toko Rafadel Acc.

Tabel 1. Sampel Data Penjualan Aksesoris

\begin{tabular}{clccc}
\hline KD & AKSESORIS & SA & ST & SAK \\
\hline AC01 & Gelang & 90 & 58 & 32 \\
\hline AC02 & Anting Cewek & 40 & 33 & 7 \\
\hline AC03 & Anting Xuping & 35 & 12 & 23 \\
\hline AC04 & Bandana Anak & 70 & 47 & 23 \\
\hline AC05 & Aseton & 58 & 28 & 30 \\
\hline AC06 & Bandana Jilbab & 48 & 45 & 3 \\
\hline AC07 & Bros Kain & 36 & 32 & 4 \\
\hline AC08 & Bulu Mata Palsu & 144 & 87 & 57 \\
\hline AC09 & Bando & 48 & 12 & 36 \\
\hline AC10 & Boneka & 36 & 23 & 13 \\
\hline AC11 & Bros & 132 & 97 & 35 \\
\hline AC12 & Bunga & 40 & 36 & 4 \\
\hline AC13 & Cincin Anak & 38 & 29 & 9 \\
\hline AC14 & Celengan & 24 & 15 & 9 \\
\hline AC15 & Cincin Titanium & 45 & 40 & 5 \\
\hline AC16 & Gelang Anak & 120 & 78 & 42 \\
\hline AC17 & Gelang Dewasa & 50 & 47 & 3 \\
\hline AC18 & Gantungan HP & 60 & 27 & 33 \\
\hline AC19 & Hena & 58 & 15 & 43 \\
\hline AC20 & Gantungan Kunci & 36 & 35 & 1 \\
\hline AC21 & Gelang Kaki & 48 & 15 & 33 \\
\hline AC22 & Ikat Pinggang & 36 & 17 & 19 \\
\hline AC23 & Jepitan & 180 & 115 & 65 \\
\hline AC24 & Jam Tangan & 65 & 27 & 38 \\
\hline AC25 & Jam Weker & 75 & 27 & 48 \\
\hline AC26 & Kotak Cincin & 96 & 39 & 57 \\
\hline Ket : SA Stok Awa1 & &
\end{tabular}

$$
\begin{aligned}
& \text { Ket : } \text { SA }=\text { Stok Awal } \\
& \text { ST }=\text { Stok Terjual } \\
& \text { SAK = Stok Akhir }
\end{aligned}
$$

Data yang sudah dijadikan sampel akan dilakukan pengolahan data dengan proses clustering dengan menggunakan algoritma $\quad K$-Means sehingga didapatkanlah hasil pengelompokan data yang diinginkan. Adapun langkah dalam cluster dengan algoritma $K$-Means yaitu :

\section{Menentukan Jumlah Cluster}

Menentukan jumlah cluster yang digunakan pada data penjualan aksesoris sebanyak 3 cluster diantaranya Paling laku, laku, kurang laku berdasarkan data penjualan dalam 1 tahun

\section{Menentukan Centroid}

Penentuan pusat awal cluster (centroid) ditentukan secara random atau acak yang diambil dari data yang ada. Nilai cluster 0 diambil dari baris ke-20, nilai cluster 1 pada baris ke-4, nilai cluster 2 pada baris ke-8.

Tabel 2. Centroid Awal

\begin{tabular}{clccc}
\hline C & AKSESORIS & SA & ST & SAK \\
\hline C0 & Gantungan Kunci & 36 & 35 & 1 \\
\hline C1 & Bandana Anak & 70 & 47 & 23 \\
\hline C2 & Bulu Mata Palsu & 144 & 87 & 57 \\
\hline
\end{tabular}

\section{Menghitung Jarak dari Centroid}

Menghitung jarak antara titik centroid dengan titik tiap objek dengan menggunakan Euclidian Distance. Adapun penghitungan centroid awal secara manual. Perhitungannya adalah sebagai berikut :

$$
\mathrm{D}(i, f)=\sqrt{\left(\mathrm{X}_{\mathrm{i} 1}-\mathrm{X}_{1 \mathrm{j}}\right)^{2}+\left(\mathrm{X}_{2 \mathrm{i}}-\mathrm{X}_{2 \mathrm{j}}\right)^{2}+\ldots+\left(\mathrm{X}_{\mathrm{ki}}-\mathrm{X}_{\mathrm{kj}}\right)^{2}}
$$

Tabel 3. Perhitungan Jarak dan Pengelompokan Data Iterasi Ke-1

\begin{tabular}{cllllll}
\hline KD & DC0 & DC1 & DC2 & C0 & C1 & C2 \\
\hline $\mathrm{AC} 1$ & 66.38 & 24.54 & 66.20 & 0 & 1 & 0 \\
\hline $\mathrm{AC} 02$ & 7.48 & 36.77 & 127.40 & 1 & 0 & 0 \\
\hline $\mathrm{AC} 03$ & 31.84 & 49.50 & 136.61 & 1 & 0 & 0 \\
\hline $\mathrm{AC} 04$ & 42.24 & 0.00 & 90.73 & 0 & 1 & 0 \\
\hline $\mathrm{AC} 05$ & 37.07 & 23.54 & 107.73 & 0 & 1 & 0 \\
\hline $\mathrm{AC} 06$ & 15.75 & 29.80 & 117.88 & 1 & 0 & 0 \\
\hline $\mathrm{AC} 07$ & 4.24 & 41.74 & 132.28 & 1 & 0 & 0 \\
\hline $\mathrm{AC} 08$ & 132.30 & 90.73 & 0.00 & 0 & 0 & 1 \\
\hline $\mathrm{AC} 09$ & 43.57 & 43.34 & 123.62 & 0 & 1 & 0 \\
\hline $\mathrm{AC} 10$ & 16.97 & 42.80 & 133.03 & 1 & 0 & 0 \\
\hline $\mathrm{AC} 11$ & 119.23 & 80.55 & 26.98 & 0 & 0 & 1 \\
\hline
\end{tabular}


Available online at http://jurnal.stmikroyal.ac.id/index.php/jurteksi

\begin{tabular}{lllllll}
\hline AC12 & 5.10 & 37.18 & 127.38 & 1 & 0 & 0 \\
\hline AC13 & 10.20 & 39.29 & 130.02 & 1 & 0 & 0 \\
\hline AC14 & 24.66 & 57.76 & 147.95 & 1 & 0 & 0 \\
\hline AC15 & 11.05 & 31.59 & 121.30 & 1 & 0 & 0 \\
\hline AC16 & 102.89 & 61.82 & 29.70 & 0 & 0 & 1 \\
\hline AC17 & 18.55 & 28.28 & 115.55 & 1 & 0 & 0 \\
\hline AC18 & 40.79 & 24.49 & 105.98 & 0 & 1 & 0 \\
\hline AC19 & 51.46 & 39.60 & 113.03 & 0 & 1 & 0 \\
\hline AC20 & 0.00 & 42.24 & 132.30 & 1 & 0 & 0 \\
\hline AC21 & 39.60 & 40.10 & 122.38 & 1 & 0 & 0 \\
\hline AC22 & 25.46 & 45.52 & 134.19 & 1 & 0 & 0 \\
\hline AC23 & 176.73 & 135.97 & 46.30 & 0 & 0 & 1 \\
\hline AC24 & 47.69 & 25.50 & 101.00 & 0 & 1 & 0 \\
\hline AC25 & 61.60 & 32.40 & 91.88 & 0 & 1 & 0 \\
\hline AC26 & 82.17 & 43.54 & 67.88 & 0 & 1 & 0 \\
\hline & & & & & &
\end{tabular}

Dari hasil perhitungan di atas didapatkan pusat cluster baru seperti Tabel sebagai berikut :

Tabel 4. Centroid Baru Iterasi Ke-1

\begin{tabular}{cccc}
\hline $\mathbf{C}$ & SA & ST & SAK \\
\hline C0 & 39.38 & 29.15 & 10.23 \\
\hline C1 & 68.89 & 31.11 & 37.78 \\
\hline C2 & 144.00 & 94.25 & 49.75 \\
\hline
\end{tabular}

Iterasi selanjutnya melakukan perhitungan lagi dengan menggunakan titik centroid yang baru Iterasi Ke-1

Tabel 5. Perhitungan Jarak dan

Pengelompokan Data Iterasi Ke-2

\begin{tabular}{cllllll}
\hline KD & DC0 & DC1 & DC2 & C0 & C1 & C2 \\
\hline AC01 & 62.20 & 34.67 & 67.42 & 0 & 1 & 0 \\
\hline AC02 & 5.06 & 42.26 & 128.04 & 1 & 0 & 0 \\
\hline AC03 & 21.83 & 41.62 & 139.15 & 1 & 0 & 0 \\
\hline AC04 & 37.67 & 21.73 & 91.78 & 0 & 1 & 0 \\
\hline AC05 & 27.18 & 13.74 & 110.34 & 0 & 1 & 0 \\
\hline AC06 & 19.44 & 42.88 & 117.59 & 1 & 0 & 0 \\
\hline AC07 & 7.64 & 47.16 & 132.79 & 1 & 0 & 0 \\
\hline AC08 & 128.37 & 95.58 & 10.25 & 0 & 0 & 1 \\
\hline AC09 & 32.13 & 28.37 & 127.16 & 0 & 1 & 0 \\
\hline AC10 & 7.54 & 41.97 & 134.50 & 1 & 0 & 0 \\
\hline AC11 & 117.45 & 91.28 & 19.21 & 0 & 0 & 1 \\
\hline AC12 & 9.28 & 44.72 & 127.68 & 1 & 0 & 0 \\
\hline AC13 & 1.85 & 42.27 & 130.97 & 1 & 0 & 0 \\
\hline AC14 & 20.94 & 55.70 & 149.47 & 1 & 0 & 0 \\
\hline AC15 & 13.29 & 41.52 & 121.44 & 1 & 0 & 0 \\
\hline AC16 & 99.47 & 69.49 & 30.00 & 0 & 0 & 1 \\
\hline AC17 & 21.99 & 42.65 & 115.13 & 1 & 0 & 0 \\
\hline AC18 & 30.79 & 10.90 & 108.90 & 0 & 1 & 0 \\
\hline AC19 & 40.26 & 20.13 & 117.14 & 0 & 1 & 0 \\
\hline AC20 & 11.44 & 49.49 & 132.48 & 1 & 0 & 0 \\
\hline AC21 & 28.16 & 26.81 & 125.61 & 0 & 1 & 0 \\
\hline AC22 & 15.36 & 40.42 & 136.30 & 1 & 0 & 0 \\
\hline AC23 & 173.62 & 141.86 & 44.26 & 0 & 0 & 1 \\
\hline AC24 & 37.84 & 5.66 & 104.41 & 0 & 1 & 0 \\
\hline AC25 & 51.96 & 12.60 & 96.37 & 0 & 1 & 0 \\
\hline AC26 & 74.10 & 34.16 & 73.55 & 0 & 1 & 0 \\
\hline & & & & & &
\end{tabular}

Dari centroid baru iterasi ke-2, dilakukan perhitungan kembali, sehingga di dapatkan hasil Tabel Perhitungan Jarak dan Pengelompokan Data Iterasi Ke-1 dimana C0 memiliki 12 data, $\mathrm{C} 1$ memiliki 10 data, $\mathrm{C} 2$ memiliki 4 data.

Berdasarkan dari perhitungan di atas bahwa pusat cluster baru iterasi ke-1 seperti Tabel sebagai berikut :

Tabel 6. Centroid Baru Iterasi Ke-2

\begin{tabular}{cccc}
\hline $\mathbf{C}$ & SA & ST & SAK \\
\hline $\mathrm{C} 0$ & 38.67 & 30.33 & 8.33 \\
\hline $\mathrm{C} 1$ & 66.80 & 29.50 & 37.30 \\
\hline $\mathrm{C} 2$ & 144.00 & 94.25 & 49.75 \\
\hline
\end{tabular}

Dari hasil centroid yang didapatkan pada iterasi ke-2,kemudian lakukan lagi perhitungan yang sama sampai data tiap cluster tidak ada lagi yang berubah.

Tabel 7. Perhitungan Jarak dan

Pengelompokan Data Iterasi Ke-3

\begin{tabular}{cllllll}
\hline KD & DC0 & DC1 & DC2 & C0 & C1 & C2 \\
\hline AC01 & 62.93 & 37.13 & 67.42 & 0 & 1 & 0 \\
\hline AC02 & 3.27 & 40.60 & 128.04 & 1 & 0 & 0 \\
\hline AC03 & 23.76 & 39.01 & 139.15 & 1 & 0 & 0 \\
\hline AC04 & 38.40 & 22.82 & 91.78 & 0 & 1 & 0 \\
\hline AC05 & 29.13 & 11.53 & 110.34 & 0 & 1 & 0 \\
\hline AC06 & 18.18 & 42.07 & 117.59 & 1 & 0 & 0 \\
\hline AC07 & 5.35 & 45.43 & 132.79 & 1 & 0 & 0 \\
\hline AC08 & 129.13 & 98.26 & 10.25 & 0 & 0 & 1 \\
\hline AC09 & 34.48 & 25.72 & 127.16 & 0 & 1 & 0 \\
\hline AC10 & 9.09 & 39.77 & 134.50 & 1 & 0 & 0 \\
\hline AC11 & 117.76 & 93.88 & 19.21 & 0 & 0 & 1 \\
\hline AC12 & 7.26 & 43.24 & 127.68 & 1 & 0 & 0 \\
\hline AC13 & 1.63 & 40.38 & 130.97 & 1 & 0 & 0 \\
\hline AC14 & 21.23 & 53.32 & 149.47 & 1 & 0 & 0 \\
\hline AC15 & 12.03 & 40.36 & 121.44 & 1 & 0 & 0 \\
\hline AC16 & 100.10 & 72.14 & 30.00 & 0 & 0 & 1 \\
\hline AC17 & 20.85 & 42.01 & 115.13 & 1 & 0 & 0 \\
\hline AC18 & 32.78 & 8.42 & 108.90 & 0 & 1 & 0 \\
\hline AC19 & 42.55 & 17.89 & 117.14 & 0 & 1 & 0 \\
\hline AC20 & 9.09 & 47.92 & 132.48 & 1 & 0 & 0 \\
\hline AC21 & 30.51 & 24.13 & 125.61 & 0 & 1 & 0 \\
\hline AC22 & 17.28 & 37.94 & 136.30 & 1 & 0 & 0 \\
\hline AC23 & 174.23 & 144.54 & 44.26 & 0 & 0 & 1 \\
\hline AC24 & 39.81 & 3.16 & 104.41 & 0 & 1 & 0 \\
\hline AC25 & 53.89 & 13.71 & 96.37 & 0 & 1 & 0 \\
\hline AC26 & 75.70 & 36.48 & 73.55 & 0 & 1 & 0 \\
\hline & & & & & &
\end{tabular}

Karena pada Iterasi Ke-2 dan Ke-3 posisi cluster tidak berubah maka iterasi dihentikan dan hasil akhir yang diperoleh yaitu: 
1. C0 memiliki 12 data yang diartikan bahwa kelompok pertama adalah kategori aksesoris kurang laku.

2. C1 memiliki 10 data yang diartikan bahwa kelompok kedua adalah kategori aksesoris laku.

3. C2 memiliki 4 data yang diartikan bahwa kelompok ketiga adalah kategori aksesoris paling Laku.

Pada Implementasi Dan Pengujian disini kita menggunakan sebuah Software RapidMiner Studio Versi 8.2, dengan pengujian data menggunakan software kita akan membandingkan bagaimana hasil pengolahan data secara manual dengan hasil pengolahan data menggunakan sebuah software.

Pada gambar 4 merupakan halaman utama dari aplikasi RapidMiner Studio v.8.2 saat pertama kali membuka aplikasi setelah proses loading selesai terlihat pada gambar berikut :

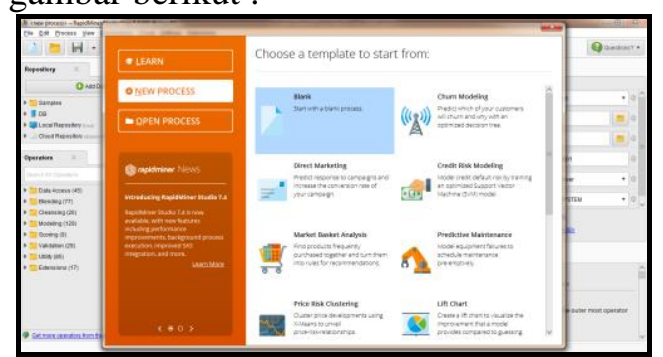

Gambar 4. Halaman Utama RapidMiner Studio v.8.2

Pada tampilan halaman utama ada lima menu yang akan digunakan yaitu :

1. Icon New Process berfungsi untuk membuat halaman proses kerja Data Mining yang baru.

2. Open Process berfungsi untuk membuka proses yang sudah ada direpository sebelumnya.

3. Learn berisikan petunjuk-petunjuk menggunakan RapidMiner Studio v.8.2.

Berikut ini adalah tampilan New Process yang akan digunakan untuk memulai proses kerja baru terlihat pada gambar 5 .

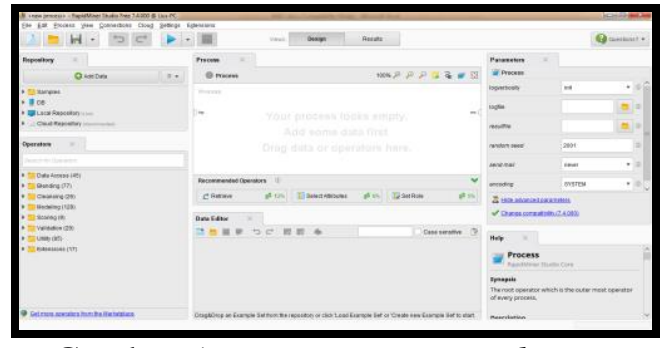

Gambar 5. New Process RapidMiner Studio v.8.2

Tampilan new process adalah untuk membuat halaman kerja pada RapidMiner Studio v.7.4. Import data dilakukan untuk memasukkan data yang akan diuji dalam bentuk format .xls atau .xlsx. Berikut adalah cara untuk melakukan import file Microsoft Excel. Untuk membuat mengimport data yang akan diproses, maka dilakukan New process, dengan cara klik kanan $\rightarrow$ Insert Operator $\rightarrow$ Data Access $\rightarrow$ Files $\rightarrow$ Read $\rightarrow$ Read Excel.

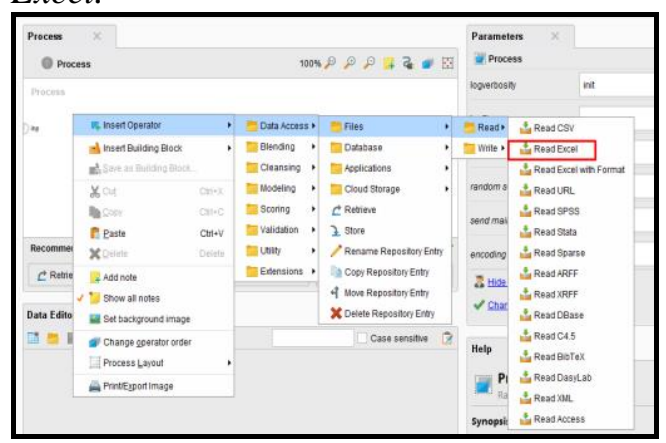

Gambar 6. Tampilan Import Data Dengan Membuat Operator Baru

Setelah selesai maka akan tampil read excel pada RapidMiner Studio v.8.2, Seperti terlihat pada Gambar 8. Setelah itu lanjutkan dengan mngklik Tab Import Configuration Wizard untuk melakukan menginputkan data dari Microsoft Excel (dengan format .xls, atau .xlsx). 
Available online at http://jurnal.stmikroyal.ac.id/index.php/jurteksi

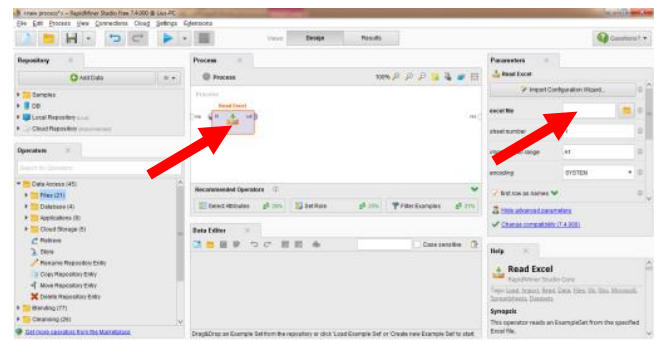

Gambar 7. Tampilan Operator Baru Read Excel.

Dalam melakukan import data pada aplikasi RapidMiner Studio v.8.2 terdiri dari 4 tahap, adapun langkah-langkahnya sebagai berikut:

\section{Data Import Wizard - Step 1 of 4}

Tahap pertama adalah mencari lokasi file yang sudah dibuat sebelumnya dengan format . $x l s x$. atau $x l s$, pilih dan kemudian simpan. Pada pengujian ini data yang akan diuji disimpan dengan nama PENJUALAN.xlsx lalu pilih diklik, seperti Gambar 8

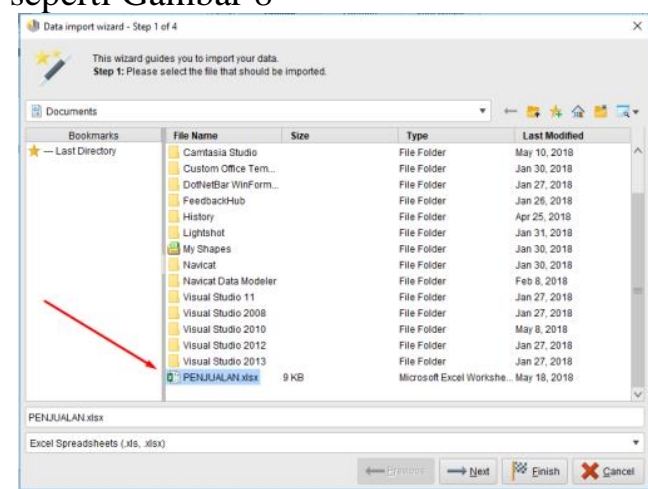

Gambar 8. Tampilan Data Import Wizard - Step 1 of 4

\section{Data Import Wizard - Step 2 of 4}

Kemudian pilih next maka lanjut ke tahap berikutnya yaitu impor wizard step 2 of 4. Pada tahap ini akan dipilih Sheet yang berisikan sumber data pada Microsoft Excel yang digunakan. Maka akan terlihat data import wizard seperti terlihat pada gambar 9 .

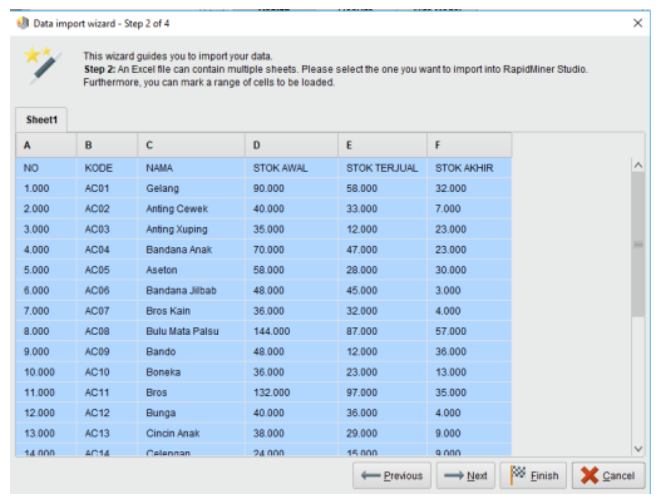

Gambar 9. Tampilan Data Import Wizard - Step 2 of 4

\section{Data Import Wizard - Step 3 of 4}

Tahap ini merupakan tahap pemberian anotasi, Jika data kita tidak memiliki nama attribute, tidak usah melakukan apa-apa pada step 3 ini. Kemudian klik tombol Next .

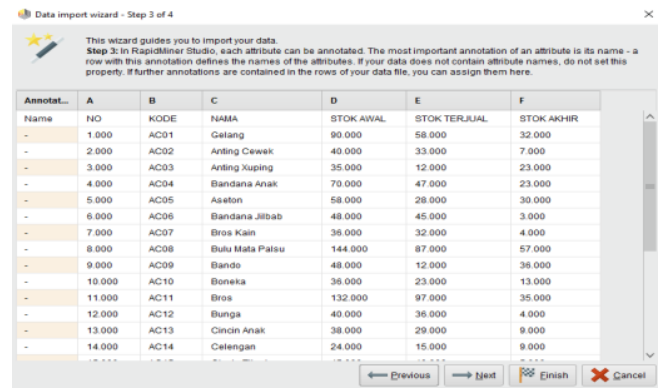

Gambar 10. Tampilan Data Import Wizard - Step 3 of 4

\section{Data Import Wizard - Step 4 of 4}

Pada Step 4, tahap ini merupakan tahap penentuan tipe data dan atribut. Sebenarnya RapidMiner Studio akan memberikan tipe data yang tepat secara otomatis. Namun, jika kita merasa tipe data yang diberikan RapidMiner Studio tidak cocok, kita bisa mengubahnya. Kumudian klik tombol Next . 


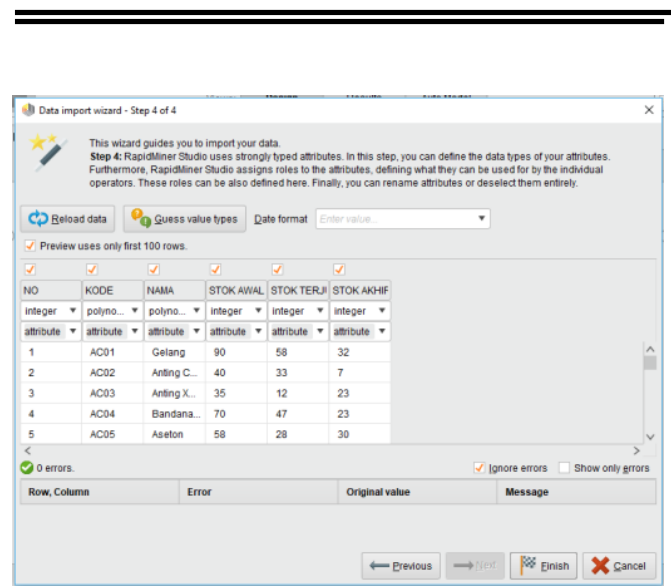

Gambar 11. Tampilan Data Import Wizard - Step 4 of 4

Tahap import data selesai dengan memilih Finish, maka pada Main Process terlihat sebuah operator baru Read Excel yang sudah berisi file PENJUALAN. $x l s x$ yang di import langsung dari file excel. Data tersebut siap dilakukan pengujian.

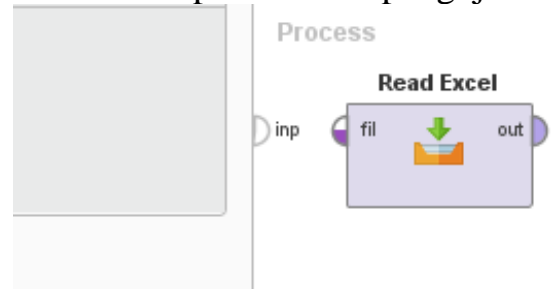

Gambar 12. Tampilan Operator Data Siap Import

Pada gambar 12 menampilkan data yang sudah di import, sehingga tombol pada operator read excel tidak ada lagi tanda seru warna kuning (menandakan operator telah berisi data dan siap diolah).

Langkah selanjutnya adalah menambahkan operator $K$-Means dengan cara klik kanan $\rightarrow$ Insert Operator $\rightarrow$ Modeling $\rightarrow$ Segmentation $\rightarrow$ K-Means.

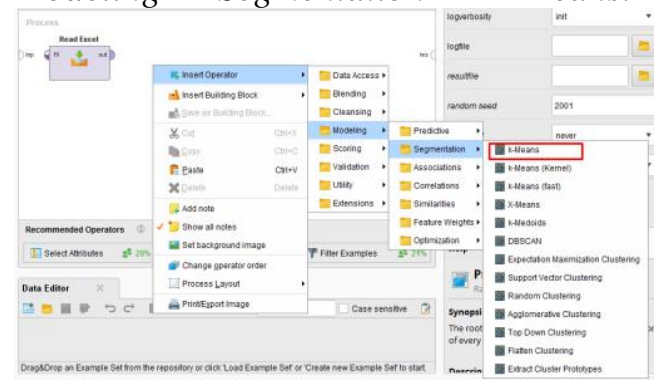

Gambar 13. Menambahkan Operator KMeans
Hubungkan data dengan clustering $k$ means untuk mengetahui output ke arah result. Apabila sudah terhubung maka tentukan jumlah cluster dan maksimal runs yang diberikan. Terakhir klik Tombol Play, $\rightarrow$ seperti pada Gambar 14.

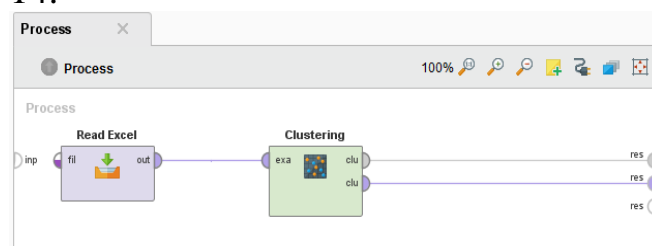

Gambar 14. Tampilan Untuk Proses $K$ Means

Selanjutnya melakukan pengaturan algoritma $K$-Means, yang diatur pada menu Parametere Clustering K-Means, seperti terlihat pada gambar 15 .

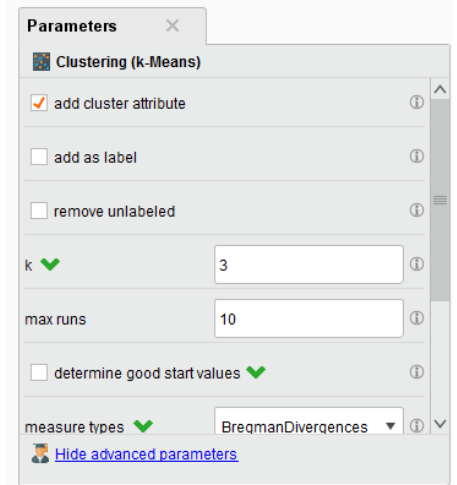

Gambar 15. Penentuan Jumlah Cluster

Pada gambar 15 di atas dilakukan pengaturan nilai $k$, di mana $k$ merupakan nilai yang digunakan untuk menentukan jumlah cluster yang akan dibentuk. Di sini jumlah cluster yang akan dibentuk adalah sebanyak 3 cluster sesuai tingkatan bahaya yaitu rendah, sedang dan tinggi.

Setelah proses running, akan tampil Example Set (Read Excel), seperti yang terlihat pada Gambar 16. 


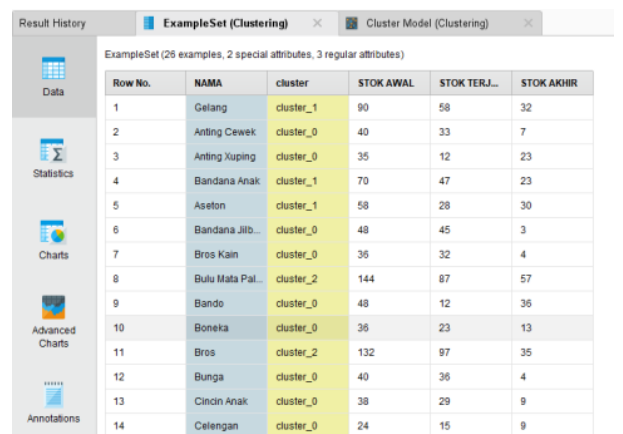

Gambar 16. Tampilan Running Data

Pada bagian Example Set terdapat beberapa bentuk hasil cluster yaitu: Data View, Statistics View, Charts, dan Annotations. Untuk Cluster model terdapat Description, Folder View, Graph View, Centroid Table, Centroid Plot View dan Annotations.

Pada Hasil Pengujian Data terdapatlah beberapa output yang dihasilkan oleh software RapidMiner v.8.2 yaitu :

\section{ExampleSet}

Pada ExampleSet dapat dilihat beberapa tampilan hasil cluster, yaitu Data View. Data View merupakan tampilan hasil cluster data secara keseluruhan sesuai dengan data yang telah diinputkan

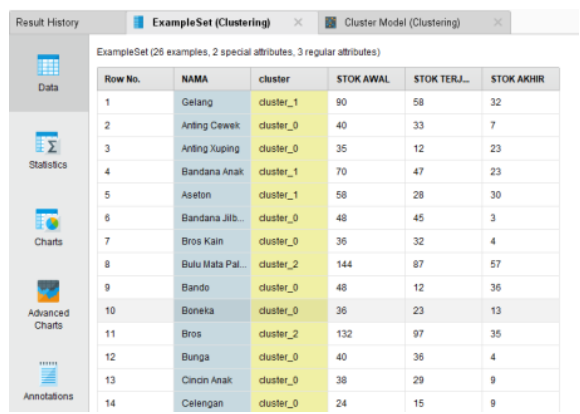

Gambar 17. Tampilan Hasil Cluster Pada Data View

Chart merupakan tampilan grafik hasil pengelompokan atau cluster sampel data nilai mata pelajaran ujian nasional dengan 3 cluster.

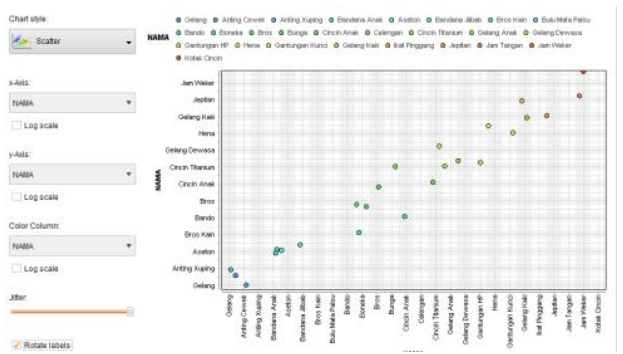

Gambar 18. Tampilan Scatter pada Chart

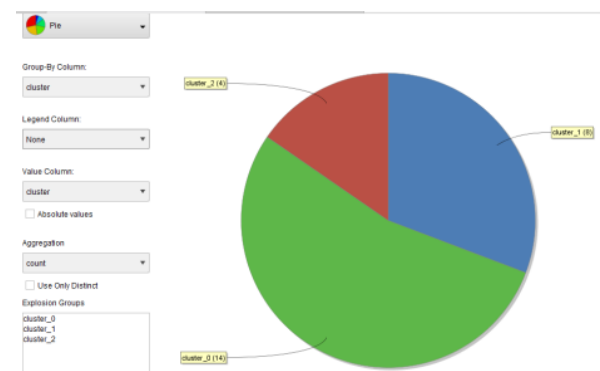

Gambar 19. Tampilan Pie pada Chart

Pada gambar 19. dapat dilihat untuk cluster 0 kategori kurang laku dengan jumlah 14 , cluster 1 kategori laku dengan jumlah 8, sedangkan cluster 2 kategori paling laku dengan jumlah 4 orang.

\section{Cluster Model (Clustering)}

Pada Cluster Model (Clustering) dapat dilihat beberapa tampilan hasil cluster, yaitu Text View yang merupakan tampilan hasil pengelompokan berdasarkan cluster dan jumlah anggotanya. Tampilan Text View akan terlihat pada gambar 5.17.

\section{Cluster Model}

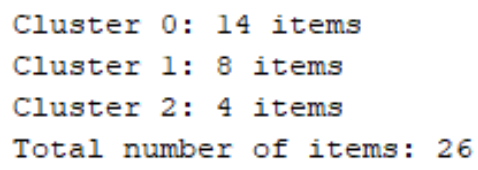

Gambar 20. Tampilan Text View 


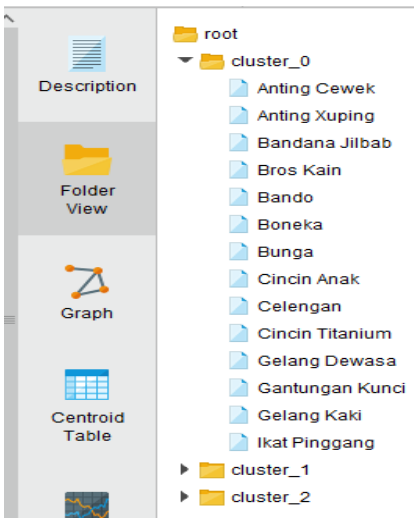

Gambar 21. Tampilan Folder View

Folder View merupakan tampilan data bagian-bagian cluster secara keseluruhan, dimana masing - masing anggota cluster menampilkan nama siswa.

\section{SIMPULAN}

Berdasarkan uraian yang sudah dikemukakan pada sebelumnya, maka dapat ditarik beberapa kesimpulan Metode Clustering dengan algoritma $K$ Means dapat digunakan untuk mengelompokkan data penjualan aksesoris berdasarkan jumlah penjualannya, yaitu Paling Laku, Laku, Dan Kurang Laku. Sehingga pihak toko dapat mengantisipasi aksesoris yang kurang laku ini bagaimana supaya

\section{DAFTAR PUSTAKA}

Sri, T.S. (2016). “Analisa Penerapan Data Mining Untuk Menenyukan Kubikasi Air Terjual Berdasarkan Pengelompokan Pelanggan Menggunakan Algoritma K-Means Clustering", 9(1).

Bendri, M.M., \& Herlina, L.S. (2015). "Analisis Clustering Menggunakan Metode K-Means Dalam Pengelompokkan Penjualan Produk Pada Swalayan Fadhila", 11(2).

Asroni \& Ronald, A. (2015). "Penerapan Metode K-Means Untuk Clustering Mahasiswa Berdasarkan Nilai Akademik Dengan Weka Interfase menjadi laku, Metode Clustering dapat digunakan untuk membantu Toko dalam melakukan pengelompokan aksesiris, Berdasarkan hasil perbandingan dengan cara manual dengan software terdapat sedikit perbedaan yang hasil manual cluster 0 berjumlah 12 , cluster 1 berjumlah 10 dan cluster 2 berjumlah 4 . Sedangkan hasil dari softwarenya cluster 0 berjumlah 14, cluster 1 berjumlah 8 , dan cluster 2 berjumlah 4 .

Peneliti menyadari adanya kekurangan dalam penulisan ini, karena keterbatasan penulis baik dalam hal waktu maupun pengetahuan. Dalam rangka memperbaiki kekurangan dan untuk penyempurnaan penelitian ini penulis memberikan beberapa saran Untuk penelitian selanjutnya dapat dilakukan dengan data yang lebih banyak dan parameter yang lebih banyak lagi serta Untuk memaksimalkan waktu proses clustering dengan algoritma K-Means, penentuan centroid awal yang baik akan membuat proses clustering dapat dilakukan dengan lebih cepat dan Untuk penelitian selanjutnya dalam hal pengektrasian data penjualan menerapkan metode Data Mining dengan algoritma yang berbeda.

Studi Kasus Pada Jurusan Teknik Informasi UMM Magelang", 18(1).

Nurul, R.W. (2015). "Implementasi Algoritma K-means Dalam Pengklasteran Mahasiswa Pelamar Beasiswa", 1(2).

Sibuea, M. L., \& Safta, A. (2017). Pemetaan Siswa Berprestasi Menggunakan Metode K-Means Clustring. JURTEKSI, 4(1), 85-92.

Risnawati, R., \& Handayani, M. (2017). penerapan Jaringan Saraf Tiruan Untuk Proyeksi Logistik Berdasarkan Prediksi Pasien Menggunakan Algoritma Backpropagation. Jurteksi, 4(1) 
Available online at http://jurnal.stmikroyal.ac.id/index.php/jurteksi 